\title{
Forensic Expertise of the Paper Support of Counterfeit Documents
}

\author{
DANIEL POTOLINCA ${ }^{1}$, IOAN CRISTINEL NEGRU ${ }^{1}$, VIORICA VASILACHE ${ }^{2}$, CECILIA ARSENE $^{3,4}$, MARIUS PADURARU ${ }^{1}$, \\ ION SANDU $2,5 *$ \\ ${ }^{1}$ Alexandru Ioan Cuza University of lasi, Faculty of Geography and Geology, 20A, Carol I Blvd., Corp B-Etaj I, 700506, Iasi, Romania \\ ${ }^{2}$ Alexandru Ioan Cuza University of lasi, Interdisciplinary Research Department - Field Science, Arheoinvest Platform, 22 Carol \\ I Blvd., Corp G-Demisol, 700506, lasi, Romania \\ ${ }^{3}$ Alexandru Ioan Cuza University of lasi, Faculty of Chemistry, 11 Carol I Blvd., 700506, Iasi, Romania \\ ${ }^{4}$ Alexandru Ioan Cuza University of Iasi, Integrated Center of Environmental Science Studies in the North Eastern Region \\ (CERNESIM), 11 Carol I Blvd., lasi, 700506, Romania \\ ${ }^{5}$ Romanian Inventors Forum, 3 Sf. Petru Movila Str., BI. L11, Sc. A., III/3, 700089 Iasi, Romania
}

\begin{abstract}
The paperwork presents the results of the examination of the paper support from travel documents, by analysing the composition of the biodata page, which where differently falsified. For this purpose, the computer analyzed the composition of the tab, which is usually through various kinds counterfeit. By taking very small fragments of these pages, we can get useful information about the methods and techniques used by counterfeiters. The comparative analysis highlights the forgeries and certain connections with the original document. Therefore, there were obtained some data on their scientific investigation and highlighted the method used by forgeries.
\end{abstract}

Keywords: passport, fibres, printing, frosted layer, counterfeit, forged

Through the forensic examination of documents, we can establish the forgery techniques used in documents, namely falsification by alteration of a genuine support, or by counterfeiting the biodata page [1,2], the role and conditioning them having a close connection with the evolution of technology [2]. The judicial expertise differs from other types of forensic investigation by purpose: to identify the counterfeiter who makes copies of valuable documents, establishing the period, the types of materials and methods for achieving document, respectively the motivation, manner and place of use. In this sense, it involves a complex technical and scientific investigation of the document in question, when determining the chemical nature of the component materials, structural and functional features, manufacturing technology, conservation status, up to the detailed identification of the archaeometric or chemometric characteristics and traces of surface materials [2-5]. An important role is held by the physico-chemical expertise of the documents with counterfeit elements or entirely falsified, which allows proof of guilt and identification of the perpetrator. The physico-chemical examination of counterfeit documents has a very important role in proving the guilt and whereabouts of the perpetrator [3, 6-13].

After 2007, when Romania became a member state of the European Union [13], at the border crossings were identified a large number of forged documents, such as: passports, identity cards, visas, credit cards and means of payment, attorney and notary documents [14, 15].

The paper analyzed a series of documents difficult to identify at first glance as being partially forged. For the identification of these counterfeited documents there were used optical microscopy (OM), scanning electron microscopy (SEM) coupled with X-ray spectroscopy(EDX), and FTIR spectroscopy.

\section{Experimental part}

Materials and methods

Three Romanian passports with counterfeited biodata page by differentmethods (fig. 1a, b and c) and one genuine

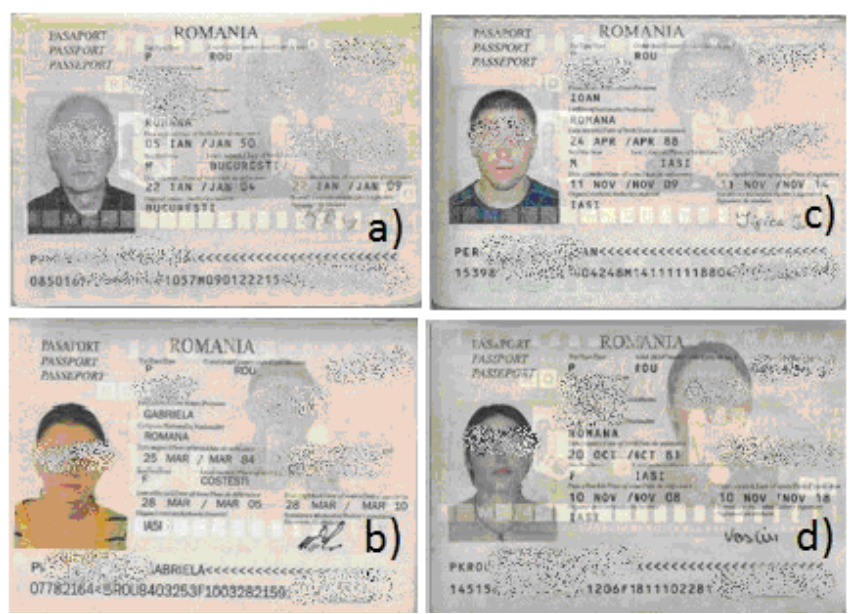

Fig. 1. Images of documents analyzed: $a, b$ and c - counterfeited; $d$ - genuine

(fig. 1d) was used for this study. Samples were collected from small areas of the biodata-pages, in order to not damage the documents.

Determination of printing technique and the fiber density was performed by optical microscopy using a CARL ZEISS AXIO IMAGER A1m, with attached camera AXIOCAM, images being enhanced between 50x and 200x and observed by reflection [16-18]. In the analysis of component materials (composition and microstructure morphology) was used, a scanning electron microscope, SEM VEGA II LSH model, manufactured by TESCAN, Czech Republic, together with an EDX detector type QUANTAX QX2, manufactured by BRUKER/ROENTEC Germany [1719].

Sample analysis was performed at a $200 \ldots . . .1000 x$ magnification, with a $30 \mathrm{kV}$ acceleration tension and the working pressure below $1 \times 10^{-2} \mathrm{~Pa}[19,20]$.

For optical and electronic microscopy SEM-EDX type were used from the peripheral areas illegible samples of the four documents, which were taken by noninvasive methods and para-destructive [20].

\footnotetext{
* email: ion.sandu@uaic.ro
} 
The elemental composition obtained by the technique SEM-EDX was corroborated with data obtained by ATRFTIR. FTIR spectra were obtained using a Vertex 70 FTIR equipped with accessories: ATR mode and RAMAN II. The spectra were recorded in the range of $4000-700 \mathrm{~cm}^{-1}$ [2123].

\section{Results and discussions \\ Microscopic analysis}

In figure $2 \mathrm{a}$ it is seen that the recto side of genuine (P1) document is secured by a protective foil TKO, specifically Transparent Kinegram Overlay (an iridescent security element based on diffractive optical device known as DOVID - Diffractive optically variable image device), and the background was printed by offset. The analysis of the P2 sample belonging to a counterfeited document (fig. $2 b)$ reveals that the TKO foil is missing. For background image was used a colour inkjet printer that use basic colors: magenta, yellow, cyan and black, highlighting the random ink dots. In the case P3 sample belonging to a support of a counterfeited document, the protection foil is deteriorated and the background was printed by color laser printing (fig 2C). In At the last sample analyzed (P4), the authentic background design was printed offset, but due to chemicals used for erasing information from biodata page, it has lost the color and clarity (fig. 2d).
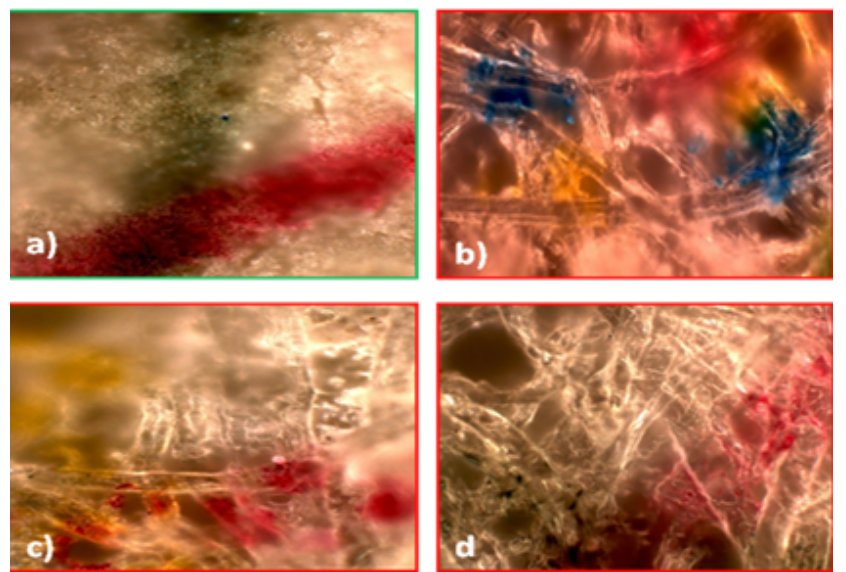

Fig. 2. OM images of samples analyzed recto: a - P1; b - P2; C - P3; d - P4

\section{SEM analysis}

The fiber composition of the paper support is a characteristic of every assortment of paper. For the manufacture of paper support for documents with high security level are mainly used cotton, textile fibers and/or silk. In contrast to commercial paper which is made of wood pulp, straw, grasses, in paper-making used for documents with a high security level, chemical bleaching agents are not used. To ensure a durable and long-term use, paper support uses special pasta, which can be part of the paper mass or just covering these supports.

For the standard sample (P1) it can be seen on the obverse, both the glaze layer between the protection foil and identifying details and a very good clarity of fibres that constitute the cellulosic support (fig 3a). In the P2 sample taken from a forged document it was not found glaze layer on the front side and it is not possible to make a clear distinction of fibres in paper composition (fig $3 \mathrm{~b}$ ). When examining the $\mathrm{P} 3$ sample one can see obvious extra paper support over the real one (fig $3 \mathrm{c}$ ), the genuine support being destroyed due to the substances used for sticking that penetrated in the mass of the paper. On both sides of the analysed bracket it appears that fibres can no longer be seen. On the last sample analysed P4 it can be seen how glaze layer and fibres of the paper composition were destroyed, due to the chemicals used for erasing information from biodata page (fig. 3d).
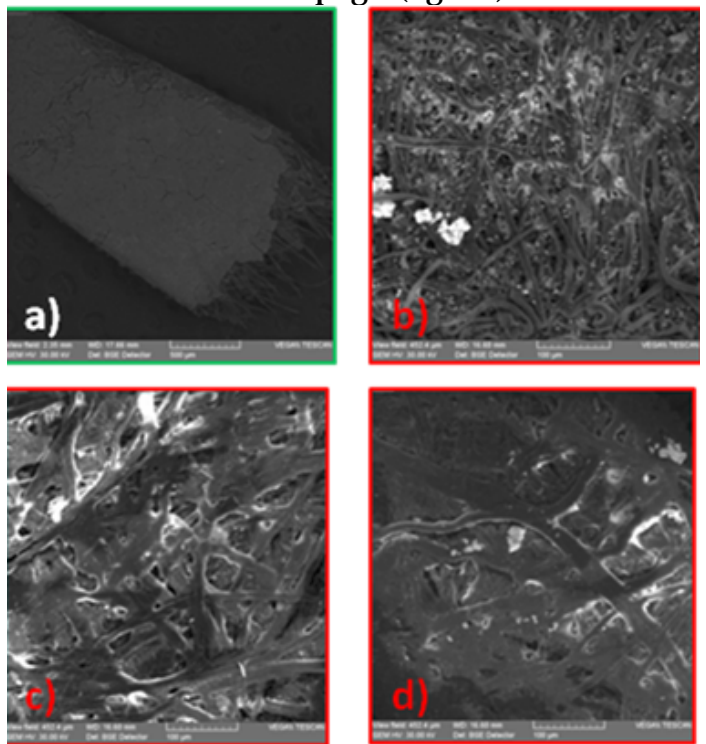

Fig. 3. SEM images of the recto pages of the analyzed samples: a - P1; b - P2; C - P3; d - P4

Examining the recto proof of the genuine document (P1) there is a higher quality of paper ground specific to documents with high security level and a very good resolution of cellulose fibres (fig 4a). For the sample P2, due to the use of ordinary paper, cellulose fibres do not longer have the same quality as the genuine document, and it can be seen a visible distinction between them (fig $4 b)$. The verso side of the sample P3 of the genuine support is altered by chemical substances used for erasing the recto side, as well as adhesive substances used for bonding the false, nearly imperceptible fibres (fig. 4c). The verso side from the latest sample P4 is similar to the third sample, the difference being given by the absence of secondary substrate and hence the lack of adhesive substances (fig. 4d).
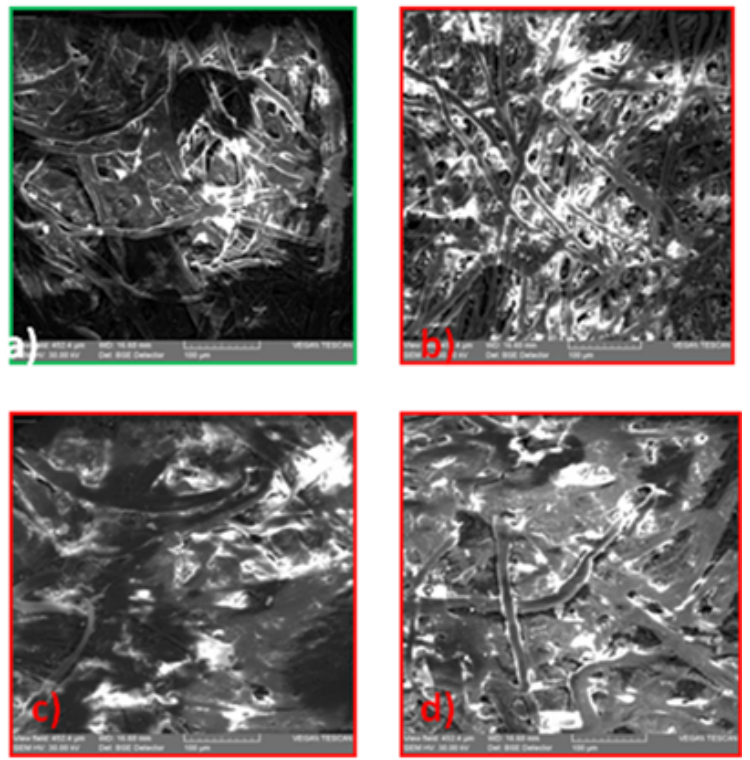

Fig. 4. SEM examination of the verso samples: a - P1; b - P2; C - P3; d - P4

The composition of the genuine (P1) and counterfeited documents (P2, P3 and P4) was examined through EDX. The results are shown in table 1 . The genuine document (P1) contains cellulose with high level of purity and on the other side has a $\mathrm{SiO}_{2}$ layer. The counterfeited documents contain on the both sides aluminum silicates powder due to the contamination with the dust (ash, dirt, etc.) 
Table 1

THE CHEMICAL COMPOSITION OF THE ANALYZED SAMPLES BY EDX

\begin{tabular}{|l|l|l|l|l|l|l|l|l|l|l|l|l|}
\hline \multirow{2}{*}{ Samples } & \multicolumn{9}{|c|}{ The elemental composition (percentage by weight) (\%) } \\
\cline { 2 - 14 } & $\mathbf{C}$ & $\mathrm{Si}$ & $\mathbf{A l}$ & $\mathrm{S}$ & $\mathbf{N a}$ & $\mathbf{K}$ & $\mathbf{C a}$ & $\mathbf{C u}$ & $\mathbf{C l}$ & $\mathbf{T i}$ & $\mathbf{0}$ \\
\hline P1- glaze & 12.057 & 25.157 & 0.453 & 0.698 & - & - & - & - & - & & 61.635 \\
\hline P1- recto & 14.644 & 3.800 & 3.833 & - & - & 0.693 & - & - & - & - & 77.030 \\
\hline P1- verso & 19.444 & 0.976 & 0.877 & - & - & - & - & - & - & - & 78.703 \\
\hline P2- recto & 12.166 & 0.322 & 0.295 & 0.237 & - & 1.048 & 8.129 & 1.501 & 0.412 & - & 75.890 \\
\hline P2- verso & 10.802 & 0.482 & 0.472 & 0.281 & 1.429 & 1.180 & 8.529 & - & 0.547 & - & 76.278 \\
\hline P3- recto & 13.242 & 2.001 & 2.449 & - & 2.303 & 0.187 & 1.713 & 1.079 & 0.178 & 2.445 & 74.403 \\
\hline P3- verso & 17.885 & 1.329 & 1.813 & - & 1.721 & 0.469 & - & - & 0.543 & - & 76.240 \\
\hline P4 - recto & 17.713 & 1.726 & 2.313 & 0.205 & 2.031 & 0.420 & 0.472 & 1.609 & 0.648 & - & 72.864 \\
\hline P4 - verso & 17.464 & 1.639 & 2.163 & - & 1.700 & 0.361 & - & - & 0.443 & - & 76.229 \\
\hline
\end{tabular}

It has been identified on the counterfeited documents elements such as $\mathrm{K}, \mathrm{Na}, \mathrm{Ca}, \mathrm{Cl}$ which come from the dry cleaning with hypochlorite [24]. Two of the counterfeited documents (P3 and P4) had obvious dry cleaning, butone document (P2) has a commercial paper instead of the biodata page. This commercial paper does not have $\mathrm{Na}^{+}$ on one side and $\mathrm{Cu}^{2+}$ on the back side as the others documents, which denote that the author did not chose very well the paper support.

In figure 5 and 6 are presented the spectra from all four samples.

The analysis of the characteristic bands of FTIR spectra are highlighted as follow $[22,23,25,26]$ :

$-2000-4000 \mathrm{~cm}^{-1}$ - the stretching vibration of the $\mathrm{OH}$ $\left(3100-3600 \mathrm{~cm}^{-1}\right), \mathrm{CH}$ and $\mathrm{CH}_{2}\left(2800-3000 \mathrm{~cm}^{-1}\right)$;

- $1500-2000 \mathrm{~cm}^{-1}$ - shows weak absorption, usually at $1650 \mathrm{~cm}^{-1}$, due to the deformation of the symmetrical vibration of water molecules (humidity pulp); at 1730-1760
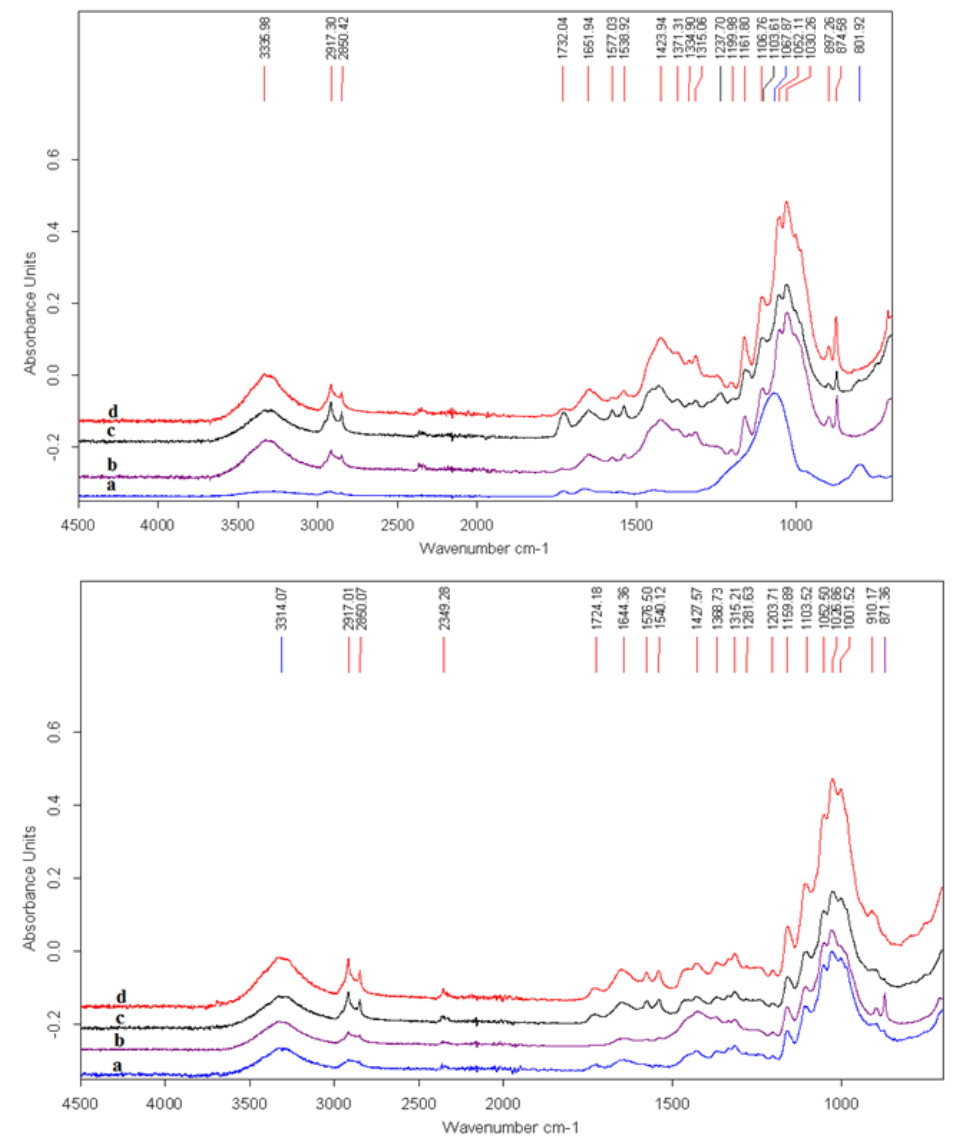

$\mathrm{cm}^{-1}$ there are bands specific to carbonyl groups present in the oxidized cellulose.

- $1200-1500 \mathrm{~cm}^{-1}$ contains a series of distinct bands which are mainly present due to primary alcoholic group $\mathrm{CH}_{2} \mathrm{OH}\left(1430,1370,1290,1240 \mathrm{~cm}^{-1}\right.$ deformation vibrations).

Additional, here are included deformation and vibration of bonds $\mathrm{C}-\mathrm{O}$ and $\mathrm{C}-\mathrm{H}$.

- Betw een $950-1200 \mathrm{~cm}^{-1}$ there are valence vibrations of the bonds $\mathrm{C}-\mathrm{O}, \mathrm{C}-\mathrm{C}$, of cycles pyranose $\left(1050 \mathrm{~cm}^{-1}\right)$ and deformation vibrations of groups $\mathrm{CH}_{2} \mathrm{OH}$.

- Between $700-950 \mathrm{~cm}^{-1}$ there is a peak at $900 \mathrm{~cm}^{-1}$, which is due to deformation vibrations of groups $\mathrm{CH}_{2} \mathrm{OH}^{\prime}$, $\mathrm{CHOH}$ and pyranose cycles.

By comparing all spectra obtained from the recto of genuine biodata page (fig. 5 a) with forged ones (b, $c$ and d), there is a clear difference between forged and genuine documents. Thus the genuine passport has clear peaks
Fig. 5. FTIR spectra of genuine (bottom) and forged (top) recto biodata page: a -P1; b - P2, c - P3; d- P4 
around $801.92 \mathrm{~cm}^{-1}$ and $1067.87 \mathrm{~cm}^{-1}$ respectively, which are associated with absorption bands of silicates. They are present in the icing on cellulosic support. The spectra from forged documents have the same appearance, but much different from the original, especially in the field of deformation vibration $\left(700-1750 \mathrm{~cm}^{-1}\right)$.

The spectra from the versos of the biodata pages, as seen in figure 6 , are largely similar, because counterfeited documents keep the original substrate for biodata page.

As result, although the verso samples are coming from four different documents, the spectral appearance of absorption bands shows no essential differences, being situated in specific regions of the frequency characteristic of cellulose used in the original document. There are only differences regarding the intensity and the frequency profile.

\section{Conclusions}

The forensic examination of suspected documents to be forged or counterfeited can be done by forensic investigations under criminal law where these documents constitute as evidence.

This study has revealed that the passport corresponding to the P2 sample was counterfeited by replacing the biodata page and maintaining the genuine protective foil. In the case of the P3 sample, the paper was dry cleaned and then a new biodata page was added over the authentic page, the protective foil being pasted again. The last passport P4 was counterfeited by reprinting the biodata page that was chemically erased.

\section{References}

1.CHAPMAN, J.P., Determining the Security Enhancement of Biometrics in E-Passports, International Center for Information Technology, Seminar Biometry \& Security, November 30, 2009, Bonn, 2009.

2.STOIAN, M.G., FERARU, D.L., Rolul expertizei fizico-chimice in stabilirea falsurilor si contrafacerilor de documente, Revista de Criminologie, Criminalistica si Penologie, 3/4, 2013, pp. 152-159.

3.STOIAN, M.G., FERARU, D.L., Expertiza fizico-chimica- mijloc de probare a falsurilor si contrafacerilor de carti de identitate si de banknote, Revista de Criminologie, Criminalistica si Penologie, 3/4, 2013, pp. 17-26.

4.INEKE, J., SPRING, M. Scanning Electron Microscopy (SEM) and Energy Dispersive X-ray Spectroscopy (EDS or EDX), In: PINNA, D., GALEOTTI, M. \& MAZZEO, R. (eds.) Scientific Examination for the Investigation of Paintings. A Handbook for Conservator-restorers, Florenze: Centro Di, 2009, pp. 191-193.

5.BUDU, A.M., SANDU, I., VASILACHE, V., SIMIONESCU, A.E., SANDU, I.C.A., Effects of Human Skin Surface Lipids on Icons Painting Layer, Rev.Chim. (Bucharest), 66, no. 8, 2015, p. 1212

6.SANDU, I., LUCA, C., SANDU, I.C.A., VASILACHE, V., Old paintings authentication through the identification of the polychrome layers materials - I. Gas-cromatography analyse, Rev.Chim. (Bucharest), 58, no. 10, 2007, p. 879

7.SANDU, I.C.A., VASILACHE, V., SANDU, I., LUCA, C., HAYASHI, M., Authentication of the Ancient Easel-paintings through Materials Identification from the Polychrome Layers III. Cross - section Analysis and Staining Test, Rev.Chim. (Bucharest), 59, no. 8, 2008, p. 855 8.SANDU, I.C.A., LUCA, C., SANDU, I., VASILACHE, V., HAYASHI, M., Authentication of the ancient easel paintings through materials identification from the polychrome layers - II. Analysis by means of the FT-IR spectrophotometry, Rev.Chim. (Bucharest), 59, no. 4, 2008, p. 384
9.SANDU, I.C.A., LUCA, C., SANDU, I., A study on the paintings clothsupports ageing degradation, Rev.Chim. (Bucharest), 50, no. 12, 1999, p. 902

10.NEGRU, C.I., POTOLINCA, D., SANDU, I., Tehnici de imprimare intalnite la documentele de calatorie, EUROINVENT - Creativity in European Context, International Workshop, lasi, 2013, pp. 153-160. 11.SANDU, I.C.A., ROQUE, A.C.A., MATTEINI, P., SCHAFER, S., AGATI, G., CORREIA, C.R., VIANA, J.F.F.P., Fluorescence recognition of proteinaceous binders in works of art by a novel integrated system of investigation, Microscopy Research and Technique, 75, no. 3, 2012, pp. 316-324.

12.SANDU, I.C.A., BRACCI, S., SANDU, I., Instrumental analyses used in the authentification of old paintings - I. Comparison between two icons of XIXth century, Rev.Chim. (Bucharest), 57, no. 8, 2006, p. 796 13.BOROTA, C.M., Printing techniques used to secure border crossing documents, International J ournal of Criminal Investigation, 2, no. 1, 2012, pp. 21-40.

14.POTOLINCA, D., SANDU, I., OLTEANU, G.I., DROCHIOIU, G., SIRBU, $V$., The study of documents counterfeit procedures by analyzing the security elements, International Journal of Criminal Investigation, 2, no. 3, 2012, pp. 221 - 233.

15.RUDNER, M., Misuse of passports: Identity fraud, the propensity to travel, and international terrorism, Studies in Conflict and Terrorism, 31, no. 2, 2008, pp. 95-11.

16.VASILACHE, V., SANDU, I., MIRCEA, O., SANDU, A.V., Study on the Conservation State of a Gilded Silver Coin from XVt Century, Discovered in Romania, International J ournal of Conservation Science, 4, Special Issue, 2013 pp, 710-714.

17.FUKUNANGA, K., OGAWA, Y., HAYASHI, S.I., HOSAKO, I., Tetrahert spectroscopy for art conservation, IEICE Electronics Express, 4, 2007, pp. 258-263.

18.DONNELLY, S., MARRERO, J.E., CORNELL, T., FOWLER, K., ALLISON, J, Analysis of Pigmented Inkjet Printer Inks and Printed Documents by Laser Desorption/Mass Spectrometry, Journal of Forensic Sciences, 55, no.1, 2010, pp. 129-135.

19. INEKE, J. \& SPRING, M. Scanning Electron Microscopy (SEM) and Energy Dispersive X-ray Spectroscopy (EDS or EDX), In: PINNA, D., GALEOTTI, M. \& MAZZEO, R. (eds.) Scientific Examination for the Investigation of Paintings. A Handbook for Conservator-restorers, Florenze: Centro Di, 2009, pp. 191-193.

20.GENESTAR, C., PONS, C.,Earth pigments in painting: characterisation and differentiation by means of FTIR spectroscopy and SEM-EDS microanalysis. Analytical and Bioanalytical Chemistry, 382, 2005, pp. 269-274.

21.MARUTOIU, C., BRATU, I., TRIFA, A., BOTIS, M., MARUTOIU, V.C., FTIR analysis of painting materials from the church saint paraschiva, of poienile izei, Maramures, Romania, International Journal of Conservation Science, 2, no. 1, 2011, pp. 29-35.

22.RUCAREAN, S.M., Conservation objects by papetar suport using nanomaterials, PhD. Thesis, Valahia University of Targoviste, IOSUD Engineering Science PhD Scool, 2014

23.MANSFIELD, J.R., ATTAS, M., MAJZELS, C., CLOUTIS, E., COLLINS, C., MANTSCH, H. H., Near infrared spectroscopy reflectance imaging: A new tool in art conservation, Vibrational Spectroscopy, 28, 2002, pp. 59-66.

24.BERTEA, A., MANEA, L.R., BERTEA, A.P., SANDU, I., Kinetics of Fenton Like Cotton Reactive Dyeing Wastewater Discoloration Process, Rev.Chim. (Bucharest), 67, no. 12, 2016, p. 2446

25.NAKAMOTO, K., Infrared and Raman Spectra of Inorganic and Coordination Compounds, Parts A and B, John Wiley \& Sons, New York, 1997;

26. COATES, J., Interpretation of Infrared Spectra, A Practical Approach, Encyclopedia of Analytical Chemistry (Editor R.A. Meyers), J ohn Wiley $\&$ Sons Ltd, Chichester, 2000, pp. 10815-10837

Manuscript received: 12.12 .2016 